\title{
A RESEARCH ON ANCILLARY PRODUCT BUYING INTENTIONS OF DOMESTIC AIRLINE PASSENGERS IN TURKEY
}

\author{
DOI: 10.17261/Pressacademia.2017.733 \\ RJBM-V.4-ISS.4-2017(13)-p.456-464
}

Ferhan Kuyucak Sengur ${ }^{1}$, Temel Caner Ustaomer ${ }^{2}$, Mustafa Uzgor ${ }^{3}$

${ }^{1}$ Anadolu University, Department of Aviation Management, Eskisehir, Turkey. fkuyucak@anadolu.edu.tr

${ }^{2}$ Anadolu University, Department of Aviation Management, Eskisehir, Turkey.temelcanerustaomer@anadolu.edu.tr

${ }^{3}$ Anadolu University, Department of Aviation Management, Eskisehir, Turkey. mustafauzgor@anadolu.edu.tr

To cite this document

Kuyucak Sengur, F.,Ustaomer, T.C. ,Uzgor, M., (2017).A research on ancillary product buying intentions of domestic airline passengers in Turkey. Journal of Management, Marketing and Logistics (JMML), V.4, Iss.4, p.456-464.

Permemant link to this document:http://doi.org/10.17261/Pressacademia.2017.733

Copyright: Published by PressAcademia and limited licenced re-use rights only.

\begin{abstract}
Purpose-In this study, the purchase intentions of Turkish domestic passengers in respect of ancillary products was determined Methodology-For this purpose a quantitative study was performed. A survey based on the literatüre review and past studies was developed and used for data collection. Data has been analyzed using Statistical Package for the Social Sciences (SPSS).

Findings-According to the results, the tendency of buying ancillary products forTurkish domestic passengers was found low. Moreover, there was not found any statistical relationship between demografic characteristics of passengers and the intention of passengers buying airlines' ancillary products.

Conclusion-In the current market, airline passengers in Turkey domestic market are not willingto buy airline ancillary products with an extra costs, however, reasonable prices might trigger the buying behaviour.
\end{abstract}

Keywords: Airline, airline passengers, ancillary product, ancillary revenue.

JEL Codes: L93, H27, M31

\section{TÜRKIYE IÇ HAT YOLCULARININ HAVAYOLU YAN ÜRÜNLERINI SATIN ALMA NIYETLERI ÜZERINE BİR ARAŞTIRMA}

\section{ÖZET}

Amaç-Bu çalışmanın amacı Türkiye'deki iç hat yolcularının havayolu yan ürünlerine dair satın alma niyetlerini ortaya koymaktır.

Yöntem-Bu amaçla nicel bir çalışma gerçekleştirilmiştir. Literatür taramasına ve geçmiş çalışmalara dayalı bir anket geliştirilmiş ve veri toplama amacıyla kullanıımışıtı. SPSS Paket Programı kullanılarak veriler analiz edilmiştir.

Bulgular-Araştırma bulgularına göre Türkiye'deki iç hat yolcularının havayolu yan ürünlerini alma eğilimleri düşüktür. Ayrıca yolcuların eğitim, cinsiyet, yaş, gelir gibi demografik özellikleri ile havayolu yan ürünlerini satın alma niyetleri arasında anlamlı bir farklıık bulunmamıştır.

Sonuç-Mevcut pazar yapısında, Türkiye'de havayolu ile iç hatlarda seyahat eden yolcuların havayollarına ek ücret ödeyerek yan ürün satın almaya istekli olmadıkları ancak uygun fiyat sunulduğunda, bunu değerlendirebilecekleri görülmektedir.

Anahtar Kelimeler: Havayolu, havayolu yolcusu, yan ürün, yan gelir.

JEL Kodları: L93, H27, M31

\section{GíRiş}

Geçmişten günümüze oldukça düşük olan havayolu endüstrisindeki kârlılık, son yıllarda artan rekabet, yükselen girdi fiyatları, ekonomik krizler, güvenlik sorunları gibi nedenlerden dolayı daha da düşük hale gelmiştir. Bu sebeple havayolu işletmeleri ayakta kalabilmek için farklı stratejiler geliştirmektedirler. Bu stratejilerden biride havayollarının daha önce bilet fiyatına dâhil olan ürünlerini ve hizmetlerini ayrı ayrı fiyatlandırarak müşterilerine sunmasıdır. Bockelie ve Belobaba (2017) yan ürünleri, hava seyahat hizmeti ile ilişkili olarak havayolları tarafından sunulan isteğe bağlı mal ve hizmetler olarak 
tanımlamaktadır. Havayolları bu sayede son yıllarda önemli miktarlarda yan gelir elde etmektedirler. Yan gelir, "bagaj ücreti ve kabinde sunulan yiyecek ve diğer hizmetler gibi, bir havayolu tarafından temel ürün ya da hizmetini farklılaştırma ya da geliştirme amacıyla bilet dışı kaynaklardan ya da hizmetlerden yaratılan gelirler"dir (Vasigh, et al.; 2012). Havayolu yan gelirleri konusunda son yıllarda önemli araştırmalar yapan ve danışmanlık hizmeti veren bir şirket olan Ideaworks ise yan geliri "yolcuya seyahat deneyimi kapsamında bilet satışı dışında direkt veya dolaylı olarak yapılan satışlar sonucu elde edilen gelir" olarak tanımlamaktadır(Ideaworks,2016:5).

Bu çalışmada Türkiye'deki iç hat yolcularının havayolu yan ürünlerine dair satın alma niyetleri incelenmektedir. Bu kapsamda, ilk olarak havayolu yan gelirleri ile ilgili alan yazında yapılmış çalışmalar incelenecektir. Daha sonra sırasıyla yan gelirlerin havayolları için öneminden, yan gelir çeşitlerinden ve Türkiye'deki havayollarının yan gelirlerinden bahsedilecektir. Son olarak ise havayolu yolcularından anket yoluyla toplanan veriler analiz edilerek yolcuların havayolu yan ürünlerine karşı tutumları ortaya konulacaktır.

\section{LITERATÜR INCELEMESI}

Havayolu yan ürünleri ve yan gelirleri konusundaki araştırmalar alanyazın için oldukça yenidir. Bu konuda bulunan sınırlı sayıdaki çalışmanın ürünlerin kabul edilebilirlik seviyesi ve satın alma konusunda yolcu tercihleri üzerine odaklandığı görülmektedir. O'Connell ve Warnock-Smith (2013) havayollarının yan ürün ve hizmet stratejilerinin oluşturulmasında, bazı yan ürün ve hizmetler için yolcu tercihini ve kabul edilebilirlik seviyesini belirlemek amacıyla bir kabul edilebilirlik ölçeği ortaya çıkarmışlardır. Garrow, Hotle ve Mumbower (2012) yan gelirlerin daha çok düşük maliyetli taşıyııılar tarafından benimsendiğini belirtmektedirler. Birçok ağ taşıyıcısı yan ürün fiyatlandırmasının diğer sistem performans hedeflerini etkilemesinden dolayı yan ürün fiyatlandırmasından vazgeçecektir. Balcombe, Fraser ve Harris (2009) yolcuların bir uçuşu seçerken dikkate aldığı hizmetleri inceleyebilmek için seçim deneyi yöntemini kullanmışlardır. Araştırmanın sonuçlarına göre yolcular hizmet kalitesini artıran ürün ve hizmetlere nispeten daha yüksek ücret ödemeyi kabul etmektedirler. Wittmer ve Rowley (2014) Avrupa'daki ekonomi sınıfında seyahat eden ağ taşıyıcıları yolcularının yan hizmet müşteri değerini ortaya koymuşlardır. Buldukları sonuçlara göre bu yolcular yan hizmetleri seyahat deneyimlerine değer eklediği sürece satın alma eğilimindedirler. Türkiye'de havayolu yan ürünleri ve yan gelirleri konusunda alanyazında rastlanan tek çalışma Peksatıcı tarafından gerçekleştirilmiştir. Peksatıcı (2016) düşük maliyetli taşıyıcılar için Türk iç hat havayolu pazarındaki yan gelir fırsatlarını incelemiştir. Çalışmanın bulgularına göre katılımcılar birçok yan ürün ve hizmet için ödeme yapmayı kabul etmektedirler. Araştırmanın bulguları ayrıca katılımcıların demografik özelliklerinin ödeme istekliliği üzerinde önemli etkilerinin olduğunu ortaya koymuştur.

\subsection{Yan Gelirlerin Önemi}

Yan gelirlerin elde edilmesini sağlayan yan ürün sunumu, her ne kadar havayolu endüstrisi için nispeten yeni bir uygulama olsa da aslında; çeşitli örnekleri birçok endüstride görmek mümkündür. Örnek olarak otomobil endüstrisi bu stratejiyi uzun zamandır kullanmaktadır. Bu endüstride temel ürün rekabetçi bir fiyata satılırken diğer ek hizmetler ayrı ayrı fiyatlandırımaktadır. Yan ürün stratejisi havayolu endüstrisinde ilk olarak düşük maliyetli taşıyıcılar tarafından uygulanmıştır. Bu havayolları bileti rekabetçi bir fiyata satarken daha önce bilet fiyatına dâhil olan birçok hizmeti ayrı ayrı fiyatlandırmaya başlamışlardır (Imbruglia, 2012:95). Düşük maliyetli taşıyıcıların iş modeli temel olarak geleneksel havayollarının sunmuş oldukları birtakım hizmetlerden vazgeçmek suretiyle elde ettikleri düşük maliyetlere ve dolayısıyla düşük fiyatlara dayanmaktadır (Şengür ve Kuyucak Şengür, 2017). Daha ucuz bilet fiyatı sunan bu taşıyıcılar ikincil havaalanlarından fiyata duyarlı olan yolcuları etkileyerek ağ taşıyıcılarına karşı etkili rekabete girebilmektedirler. İsteğe bağlı hizmetlerin ücretlendirilmesi ek gelir oluşmasına ve maliyet azalmasına katkıda bulunmaktadır. Örneğin, bagaj ücretleri taşınan bagaj miktarını azaltmakta, yiyecek ile içeceğin satılması ise tasfiye problemini azaltmaktadır (Wit ve Zuidberg, 2012:21).

Artan rekabet, devam eden serbestleşme, değişken çevre koşulları son yıllarda havayolu gelirlerinin azalmasına neden olmaktadır. Bu durum küresel olarak havayollarının reklam, havayolu ürünlerinde hizmet ayrıştırma gibi ikincil kaynaklardan ek gelir yaratma yolları aramasına neden olmaktadır (O'Connell ve Warnock-Smith,2013:12).

IdeaWorks (2016) taşıyıcıların yan gelir yaratma yeteneklerini dikkate alarak havayolu kategorileri oluşturmuştur. Bu şekilde oluşturulan dört kategori şu şekildedir:

- Geleneksel Havayolları: Bu kategorideki havayollarının yan gelirleri daha çok koltuk seçimi, fazla bagaj ve sık uçucu programlarından elde ettikleri gelirlerden oluşmaktadır. Bu kategorideki havayollarına örnek olarak Yeni Zelanda Havayolları ve Türk Hava Yolları verilebilir.

- Büyük Amerikan Havayolları: Amerika Birleşik Devletleri merkezli büyük havayolları bagaj ücretleri ve sık uçan yolcu programları gelirleriyle birlikte önemli miktarda yan gelir elde etmektedirler. Bu gruptaki havayollarının faaliyet gelirleri içerisindeki yan gelir yüzdeleri 2016 yılında sık uçan yolcu gelirlerindeki iyileşmeler sayesinde \%12.3'e yükselmiştir. Bu havayollarına örnek olarak Delta, Alaska, ve United havayolları verilebilir. 
- Yan Gelir Şampiyonları: Bu kategorideki havayolları faaliyet gelirleri içindeki en yüksek yan gelir oranına sahip havayollarıdır. Bu havayollarına örnek olarak Eurowings, Allegiant, Flydubai, Ryanair ve Hong Kong Express verilebilir.

Düşük Maliyetli Taşıyıcılar. Bu tip havayolları yüksek seviyede yan gelir elde edebilmek için alakart ürün ve hizmet satışlarına önem vermektedir. Bu gruptaki havayollarının faaliyet gelirleri içerisindeki yan gelir yüzdeleri 2016 yılında \%11.8 olarak gerçekleşmiştir

Tablo 1: 2016 Yılı için Taşıyıcı Türüne Göre Yan Gelir Tahminleri

\begin{tabular}{|l|c|c|c|}
\hline Havayolu Kategorisi & $\begin{array}{c}\text { Toplam Yan Gelir } \\
\text { (milyar) }\end{array}$ & $\begin{array}{c}\text { Sık Uçan Yolcu \& } \\
\text { Komisyon Bazlı (milyar) }\end{array}$ & Alakart (milyar) \\
\hline Geleneksel Havayolları & $\$ 26.9$ & $\$ 9.4$ & $\$ 17.5$ \\
\hline Büyük ABD Havayolları & $\$ 20.2$ & $\$ 12.1$ & $\$ 8.1$ \\
\hline Yan Gelir Şampiyonları & $\$ 13.4$ & $\$ 0.7$ & $\$ 12.7$ \\
\hline Düşük Maliyetli Taşıyııılar & $\$ 6.9$ & $\$ 0.3$ & $\$ 6.6$ \\
\hline Küresel Toplam & $\$ 67.4$ & $\$ 22.5$ & $\$ 44.9$ \\
\hline
\end{tabular}

Kaynak: Ideaworks, 2016

\subsection{Havayolu Endüstrisindeki Yan Gelir Çeşitleri}

Ideaworks'e göre havayolu endüstrisindeki yan gelirler dört kategori altında incelenebilir. Bu kategoriler şunlardır; alakart ürünlerden elde edilen yan gelirler, komisyon bazlı yan gelirler, sık uçan yolcu programlarından elde edilen yan gelirler ve reklam ve sponsorluk gibi kaynaklardan elde edilen diğer yan gelirler (Ideaworks, 2016). Illerleyen bölümde bu kategorilerden, havayolları tarafından sıklıkla kullanılan ilk ikisiyle ilgili bilgiler verilecektir. Bu çalışmadaki analizlerde havayolları tarafından daha sıklıkla başvurulması nedeniyle ilk iki kategori kullanılacaktır.

\subsubsection{Alakart Fiyatlama}

"Alakart" terimi havayolu endüstrisine turizm endüstrisinden geçmiştir. Alakart, daha önce havayolu bilet fiyatına dâhil olan hizmetlerin ayrı ayrı fiyatlandırılması anlamına gelmektedir (O'Connell\& Williams, 2011, s. 148). Bu uygulama, yolculara ödemeye hazır oldukları ürünleri ve hizmetleri seçme özgürlüğü vermektedir (Belobaba, 2015). Havayollarının yan gelir elde etmedeki başarısı sunulan ürün ve hizmetlerin yolcunun seyahat deneyimine ek fayda sağlamasına bağlıdır (O'Connell\&Warnock-Smith, 2013, s. 19). Havayollarının alakart fiyatlamaya tabi tuttuğu ürün ve hizmetlerden bazıları şunlardır; koltuk seçimi, fazla bagaj, eve bagaj dağıtım hizmeti, daha geniş koltuk, bilet fiyatı sabitleme, rezervasyon değişikliği ve iptali, kabinde kablosuz internet erişimi. Havayolları bahsedilen bu ürün ve hizmetleri ayrı ayrı fiyatlandırarak yan gelir yaratmaktadır. Alakart fiyatlama "hizmet ayrıştırma" anlamına da gelmektedir.

\subsubsection{Komisyon Bazlı Yan Gelirler}

Komisyon bazlı yan gelirler havayollarının; üçüncü tarafların otel konaklaması, araba kiralama ve seyahat sigortası gibi hizmetlerinin satışından elde ettikleri gelirlerdir (Sorensen\&Lucas, 2011). Üçüncü taraf ile havayolu, bu hizmetlerin müşteriye sunulması konusunda anlaşma yapmaktadır. Bu anlaşma neticesinde havayolu, müşterinin ödediği ücretten kendisine belirli bir oranda komisyon almaktadır. Komisyon bazlı hizmetler havayolunun ana ürünü olan koltuk satışının tamamlayıcısı niteliğindedirler ve havayolunun internet sitesinden satın alınabilirler. Örneğin, 2015 yılında Allegiant Havayolları yolcularına komisyon bazlı olarak 452,272 gecelik otel ve 1,204,982 gün araba kiralama hizmeti satmıştır. Havayolun komisyon bazlı gelirleri 40 milyon dolara ulaşmıştır (Ideaworks, 2016). 2014 yılında havayollarının internet sitelerinden yapılan rezervasyon oranının \%30'a ulaşması (SITA, 2014) havayolları için komisyon bazlı hizmetlerin gelecekte daha önemli olacağını göstermektedir.

\subsection{Türkiye'deki Havayollarının Yan Gelirleri}

Türk tescilli havayollarından Pegasus, THY ve Onur Air'in yan gelir performansları konusunda edinilen bilgilere göre, 2015 yılında Pegasus'un yan gelirleri 246,312,024 ABD Dolarına ulaşarak toplam gelirlerinin \%19'unu teşkil etmiştir. Pegasus'un yan gelir elde ettiği hizmetler şunlardır; uluslararası uçuşlarda satılan gümrüksüz ürünler, yiyecek ve içecek satışları, fazla bagaj ücretleri, havaalanı check-in, rezervasyon değişikliği ve iptali ücretleri ve koltuk seçimi ücretleridir (Ideaworks, 2016:36). Aynı yılda Türkiye'nin bayrak taşıyıcısı olan Türk Hava Yolları (THY)'nın yan gelirlerine bakıldığında, toplam gelirlerinin sadece $\% 2,5$ kadarını oluşturduğu ve bu gelirin daha çok sık uçan yolcu programlarından ve fazla bagaj ücretlerinden kaynaklandığı görülmektedir (Ideworks, 2016: 14).

Onur Havayolları ise, yan gelirlerini uçak içi yiyecek ve içecek satışından, fazla bagaj ücretlerinden, koltuk seçiminden ve havaalanı ulaşım ücretlerinden sağlamaktadır. Havayolu, aynı zamanda seyahat sigortası ve araba kiralama hizmetlerinden 
de komisyon bazlı gelir elde etmektedir. İç hat uçuşlarında gelirlerinin yalnızca \%2'si yan gelirlerinden oluşmaktadır. Bu oran, Pegasus'un \%19'luk oranına nazaran oldukça düşüktür (Peksatıcı, 2016:34).

\section{YÖNTEM VE BULGULAR}

Çalışmada Türkiye iç hat havayolu yolcularının havayolu yan ürünlerine karşı eğilimlerini incelemek üzere veri toplama aracı olarak anket kullanılmıştır. Anket, hızlı, güvenilir ve sistematik bilgi elde etmek için önemli bir araçtır. Anketin, diğer veri toplama tekniklerine (gözlem, görüşme) göre maliyetinin daha düşük olması ve farklı bölgelerden çok daha büyük gruplara hızlı uygulama olanağının olması gibi avantajları vardır. Anketin sınırlılıklarını ise cevaplayanı güdülemede sorunlar yaşanması, önceden hazırlanan soruların cevaplanmasının gerekliliği (esnek olmaması) ve daha çok yüzeysel bilgi toplamaya uygun olması oluşturmaktadır (Wolf, 1988'den aktaran Büyüköztürk, 2005). Bu çalışmada kullanılan anketteki bazı soru ve ifadeler yazarların izni alınarak O'Connell ve Warnock-Smith'in (2013) çalışmasından uyarlanmıştır. Ayrıca, Türkiye'de faaliyet gösteren havayollarının İnternet siteleri incelenerek ve Türk yolcuların satın alma alışkanlıkları da değerlendirilerek ankete maddeler eklenmiştir. Ankete son hali verilmeden önce anket alan uzmanlarına (akademisyenler ve havayolu pazarlama yöneticilerine) inceletilmiştir. Daha sonra ise ankette anlaşılmayan ifadelerin olup olmadığını anlamak için 5 katılımcıyla pilot bir çalışma gerçekleştirilmiştir. Daha önce uçuş deneyimi olan 416 kişiye çevrimiçi ortamda yapılan anketler vasıtasıyla toplanan veriler, SPSS 15.0 paket programı kullanılarak analiz edilmiştir. Veriler, 21 Nisan - 20 Haziran 2017 tarihleri arasında toplanmıştır. Geçerli bulunarak analize dahil edilen toplam anket sayısı 385'dir. Aşağıdaki grafikte de görüleceği üzere yolcuların \%9,7'si (37 kişi) daha önce 1 ya da 2 uçuş deneyimlerken; \%6,8'i (26 kişi) 3 ya da 4 uçuş, \%83,5 (322 kişi) gibi önemli bir kısmı ise 5 ve daha fazla uçuş deneyimine sahiplerdir.

\section{Grafik 1: Katılımcıların Uçuş Sıklığı}

1-2 uçuş

- 3-4 uçuş

5 ya da daha

fazla uçuş

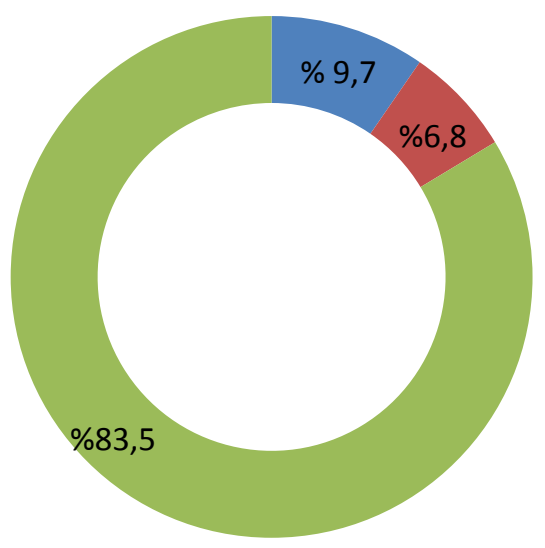

Katılımcıların uçuş amaçları arasında ilk sırayı \%38,3 ile iş amaçlı seyahatler almıştır. Tatil amaçlı uçuşlar \%32,8'lik bir orana sahip iken, arkadaş ve aile ziyareti amacıyla uçan yolcular örneklemdeki tüm yolcuların \%25,2'lik bir kısmını oluşturmaktadır. 14 yanıt ile \%3,7'lik orana sahip diğer uçuş amaçları içerisinde daha çok eğitim amacı ön plana çıkmakla birlikte, askerlik ve umre amacı gibi cevaplar da yer almaktadır. Grafik 2, havayolu yolcularının uçuş amaçlarına göre dağılımını göstermektedir. 


\section{Grafik 2: Uçuş Amaçlarına Göre Katılımcıların Dağııımı}

-Tatil Amaçlı

- iş Amaçlı

- Arkadaş/aile Ziyareti Amaçlı

- Diğer

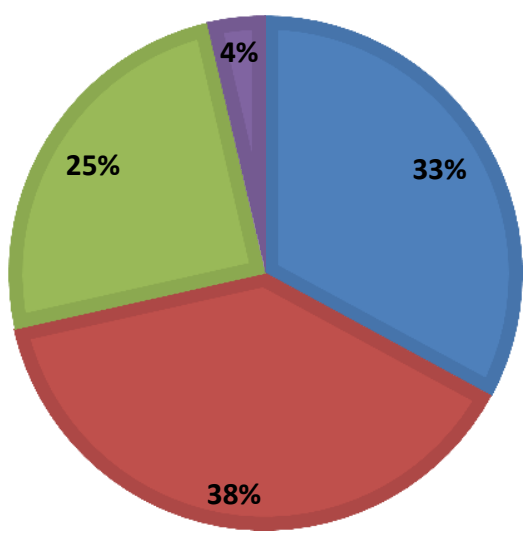

Grafik 3, katılımcıların hangi havayolu işletmesi ile seyahat etmeyi tercih ettiklerini, göstermektedir. Buna göre \%43,7'lik bir oranla katılımcıların 169'u Türk Hava Yolları'nı (THY) tercih ederken, onu sırayla Pegasus $(\% 24,6)$, Anadolujet $(\% 16,5)$, AtlasGlobal $(\% 4,7)$, SunExpress $(\% 4,7)$, OnurAir $(\% 2,6)$, Diğer $(\% 2,1)$ ve Borajet $(\% 0,5)$ takip etmiştir.

\section{Grafik 3: Yolcuların Tercih Ettiği Havayolu İşletmelerinin Dağılımı}

$$
\begin{aligned}
& \text { THY } \\
& \text { Pegasus } \\
& \text { Anadolujet } \\
& \text { AtlasGlobal } \\
& \text { SunExpress } \\
& \text { OnurAir } \\
& \text { BoraJet } \\
& \text { Diğer }
\end{aligned}
$$

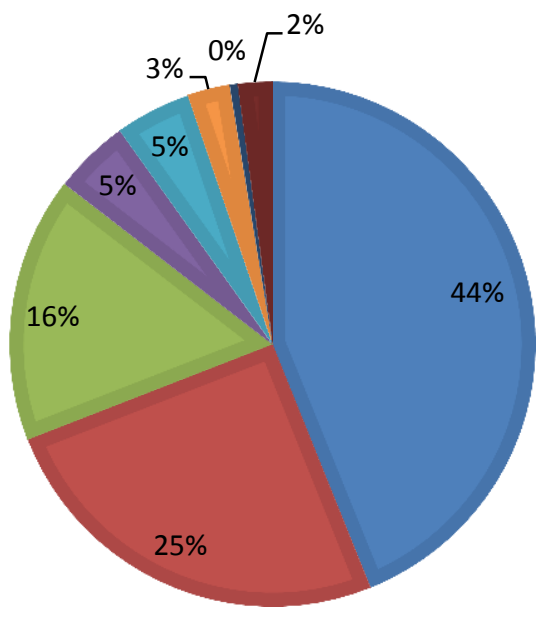

Katılımcıların yaptıkları son uçuşlarında havayolu yan ürünlerinden hangilerini satın aldıklarını sorulduğunda, 218 katılımcının daha önce hiçbir havayolu yan ürünü için ekstra para ödemediği sonucuna varılmıştır. Bu, örneklem sayısının \%57'sine karşılık gelmektedir. Bu soruda katılımcılara birden fazla seçenek seçebilme imkânı verilmiştir. Tablo 2'de görüleceği üzere kalan 162 yolcunun 76'sı daha önce koltuk seçimi için, 65'i yiyecek içecek için, 38'i fazladan bagaj hakkı için, 35'i esnek bilet için, 16 'sı bilet fiyatını sabitlemek için, $8^{\prime}$ i ise uçağa öncelikli giriş hizmetleri için bilet fiyatı haricinde para ödeyerek satın aldıklarını belirtmişlerdir. 
Tablo 2: Daha Önce Belirli Havayolu Yan Ürünlerini Satın Alan Katılımcı Sayıları

\begin{tabular}{|l|c|}
\hline Havayolu Yan Ürünü & Daha önce satın alan katılımcı sayısı \\
\hline Koltuk Seçimi & 76 \\
\hline Yiyecek içecek & 65 \\
\hline Fazladan bagaj hakkı & 38 \\
\hline Esnek bilet & 35 \\
\hline Bilet fiyatını sabitleme & 16 \\
\hline Uçağa öncelikli biniş & 8 \\
\hline
\end{tabular}

Ankete katılan yolcuların demografik özelliklerine bakıldığında katılımcıların \%46'sının kadın, \%54'ünün erkek olduğu görülmüştür. Katılımcıların \%15,4'ü 18-24 yaş aralığında, \%38'i 25-34 yaş aralığında, \%27,5'i 35-44 yaş aralığında, \%13,9'u 45-54 yaş aralığında, \%4,2'si 55-64 yaş aralığında, \%0,5'i ise 65 ve üzeri yaştadır. Katılımcıların \%0,3'ü ilköğretim mezunu, $\% 13,1^{\prime} \mathrm{i}$ ortaöğretim (lise), \%57,3'ü üniversite, \%28,8'i ise yüksek lisans/doktora mezunudur. Katılımcıların \%17,3'ü 10002000 gelir aralığında, \%25,1'i 2000-4000 gelir aralığında, \%25,9'u 4000-6000 gelir aralığında, \%12,6'sı 6000-8000 gelir aralığında bulunmakta, $\% 18,6$ 'sı ise 8000 ve üzeri gelir elde etmektedir.

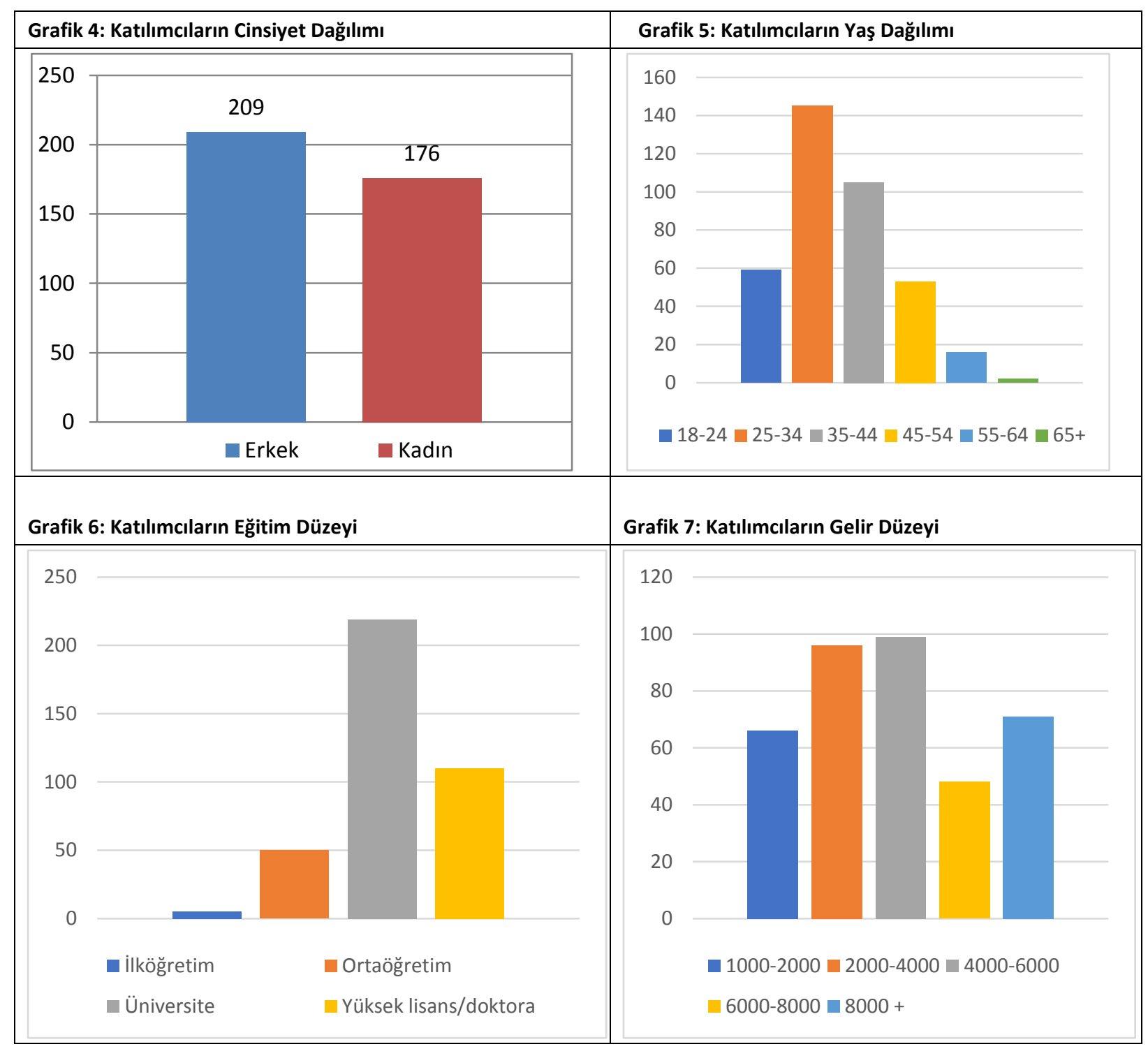


Yolcuların daha önce tanımlanan alakart hizmetlerin hangisine ne kadar bedel ödemeye yatkın olduklarına dair bilgiler, Tablo 3'de gösterilmektedir.

Tablo 3: Katılımcıların Havayolu Yan Ürünleri için Ödemeye Razı Oldukları En Fazla Ücretler

\begin{tabular}{|l|c|c|c|}
\hline Havayolu Yan Ürün Çeşidi & $\begin{array}{c}\text { Ödeyebilecekleri En Fazla } \\
\text { Ücreti Belirten Yolcular }\end{array}$ & Ortalama (TL) & Standart Sapma \\
\hline Alkolsüz İçecek & $\% 77,9$ & 5,74 & 3,10 \\
\hline Sandviç & $\% 76,6$ & 8,19 & 4,48 \\
\hline Ücretli Bagaj (kg) & $\% 68,9$ & 4,86 & 3,16 \\
\hline Sıcak Yemek & $\% 64,7$ & 16,73 & 8,17 \\
\hline Koltuk Seçimi & $\% 53,2$ & 11,89 & 8,50 \\
\hline Alkollü İecek & $\% 51,8$ & 15,53 & 9,54 \\
\hline Uçakta İnternet & $\% 46,6$ & 9,70 & 7,07 \\
\hline $\begin{array}{l}\text { Özel bekleme salonu (Lounge) } \\
\text { Hizmeti }\end{array}$ & $\% 45,0$ & 22,85 & 16,11 \\
\hline Uçak İçi Eğlence & $\% 36,1$ & 10,31 & 8,97 \\
\hline Uçağa Binişte Öncelik & $\% 30,2$ & 15,39 & 12,77 \\
\hline
\end{tabular}

Buna göre yolcuların $\% 77,9^{\prime}$ u uçuş esnasında alkolsüz bir içecek için ödeyebilecekleri en yüksek ücreti belirtmişlerdir. Bunu sandviç, ücretli bagaj ve sıcak yemek izlemektedir. Yolcuların yan ürünler için ödemeye razı oldukları en yüksek ücret ise havaalanlarındaki özel bekleme salonları için çıkmıştır. Bunu sıcak yemek, alkollü içecek ve uçağa binişte öncelik takip etmektedir. Araştırmaya katılanların büyük bir kısmı uçak içi eğlence ve uçağa binişte öncelik için ödemeye razı oldukları en yüksek fiyatı belirtmekten kaçınmışlardır.

Yolcuların bir sonraki iç hat uçuşlarında hem alakart hem de komisyon bazlı havayolu yan ürünlerini alma ihtimalleri sorulduğunda elde edilen bulgular ise Tablo 4'te gösterilmektedir.

Tablo 4: Yolcuların Havayolu Yan Ürünü Satın Alma İhtimalleri

\begin{tabular}{|l|c|}
\hline Havayolu Yan Ürün Çeşidi & $\begin{array}{c}\text { Ürünün Yolcular Tarafından Satın Alınma } \\
\text { Ihtimali (Likert Ortalaması) }\end{array}$ \\
\hline Otel rezervasyonu & 2,11 \\
\hline Koltuk Seçimi & 2,44 \\
\hline Araç kiralama & 2,33 \\
\hline Fazla bagaj & 2,65 \\
\hline Seyahat sigortası & 2,61 \\
\hline Uçağa girişte öncelik & 1,81 \\
\hline Otopark & 2,35 \\
\hline Yiyecek içecek & 2,76 \\
\hline Havaalanı Ulaşım & 2,75 \\
\hline Bilet fiyatı sabitleme & 2,71 \\
\hline Tur paketi & 2,30 \\
\hline Uçakta Internet & 2,35 \\
\hline Havaalanı özel bekleme salonu (lounge) & 2,37 \\
\hline Esnek bilet & 2,87 \\
\hline Güvenlikten hızı geçiş noktaları & 2,36 \\
\hline Adrese bagaj & 2,23 \\
\hline Kişisel ekipman & 2,29 \\
\hline Uçak içi eğlence & 2,16 \\
\hline
\end{tabular}

Anketin bu sorusunda 5'li Likert ölçeği kullanılmıştır. Yolculardan bir havayolu yan ürününü alma ihtimali en yüksek olanlar 5'i seçerken, en düşük olanlar 1'i seçmiştir. Tabloya göre 2,87 ile Likert ortalaması en yüksek olan Esnek bilet uygulaması, yolcuların satın alma potansiyelinin en yüksek olduğu yan üründür. Esnek bileti sırasıyla yiyecek içecek ve havaalanı ulaşım takip etmiştir. Öte yandan yolcular için en anlamsız bulunan yan ürün ise uçağa girişte öncelik olmuştur. Bununla birlikte hiçbir yan ürünün Likert ortalaması 3'e ulaşamamıştır. Bu ise yolcuların havayolu yan ürünlerine bilet ücreti haricinde para ödemek konusunda kararsız, ancak almamaya daha yatkın oldukları anlamına gelmektedir. Havayolu yolcularının cinsiyetlerinin bir havayolu yan ürünü almaya etkisi olup olmadığını anlamak için yapılan bağımsız T testi sonuçlarına göre 
cinsiyet ile havayolu yan ürünlerini satın alma ihtimali arasında anlamlı bir farklılık yoktur $(t(378)=1,044 ; 0,297>05)$. Havayolu yan ürününü almada yaş grubunun, eğitim durumunun ve gelir düzeyinin etkili olup olmadığını anlamak için ise ANOVA testleri yapılmıştır. Tek faktörlü varyans analizi sonuçlarına göre yaşın havayolu yan ürünlerini alma ihtimali arasında anlamlı bir farklılık yoktur $(F(5,374)=1,203,0,307>.05)$. Aynı şekilde, eğitim ve gelir ile havayolu yan ürünleri alma ihtimali arasında da anlamlı bir farklılı̆ın olmadığı sonucuna ulaşılmıştır $(F(3,376)=0,265,0,850>.05) ; F(4,375)=0,848,0,495>.05)$.

Bununla birlikte yapılan ANOVA testleri sonucunda tercih edilen havayolu işletmesi ile yan ürün alma ihtimali arasında anlamlı bir farklılık vardır $(F(7,372)=2,235 ; 0,031<.05)$. Farklılıkların hangi ikili gruptan kaynaklandığını gösteren çoklu karşılaştırma Tukey testi sonuçlarına bakıldığında Pegasus'un yolcularının yan ürün satın alma ihtimalleri (Ort. $=2,29 ; S . S .=0,51)$ ile Türk Hava Yolları (Ort. $=2,51 ; S . S .=0,55)$ yolcularının yan ürün satın alma ihtimalleri arasında anlamlı bir farklılık olduğu görülmüştür. Bu sonuca göre Türk Hava Yolları yolcularının yan ürün satın alma ihtimali Pegasus yolcularına göre daha yüksektir.

\section{SONUÇ VE ÖNERILER}

Son yıllarda dünyada özellikle bazı havayolları tarafından yaygın biçimde uygulanmaya başlanan ürün ve hizmetleri bilet fiyatından ayrıştırarak tek tek ücretlendirme politikası, havayollarına önemli miktarlarda yan gelir elde etme imkânı vermektedir. Avrupalı ve ABD’li havayollarının sıklıkla başvurduğu bu strateji Türkiye'deki havayolları için henüz oldukça yenidir. Çalışma kapsamında Türkiye iç hat yolcularının havayolu yan ürünlerini alma konusundaki davranışları incelenmiştir.

Havayolu yolcularına uygulanan anketin sonuçlarına göre esnek bilet uygulaması, yolcuların satın alma potansiyelinin en yüksek olduğu yan üründür. Esnek bileti sırasıyla yiyecek içecek ve havaalanına ulaşım takip etmiştir. Öte yandan yolcular için en az tercih edilme potansiyeli olan yan ürün ise uçağa girişte öncelik olmuştur. Bununla birlikte hiçbir yan ürünün Likert ortalaması 3'e ulaşamamıştır. Bu ise yolcuların havayolu yan ürünlerine bilet ücreti haricinde para ödemek konusunda kararsız, ancak almamaya daha yatkın oldukları anlamına gelmektedir. Yolcular, "yan ürünlerden hangileri için en fazla ne kadar ödersiniz" diye sorulduğunda en yüksek ücreti havaalanlarındaki özel bekleme salonları ve sıcak yemek için ödeyebileceklerini belirtmişlerdir. Yolcuların en az miktarda ödeme yapmaya niyetli olduğu kategori ise kg başına fazla bagaj ve alkolsüz içeceklerdir. Burada, yine yolcuların büyük bir kısmı alkolsüz içecekler, sandviç ve fazla bagaj için ödemeye razı oldukları en yüksek tutarı belirtirlerken uçak içi eğlence ve uçağa binişte öncelik ürünleri konusunda ücret belirtmekten kaçındıkları görülmektedir. Yolcuların demografik özellikleri ile havayolu yan ürünlerini satın alma ihtimalleri arasında ise anlamlı bir farklılığa rastlanmamıştır. Bu demografik özelliklerden araştırmacıları en çok şaşırtanı yolcuların gelir düzeyleri olmuştur. Bununla birlikte bir sonraki uçuşlarında THY'yi tercih eden yolcuların havayolu yan ürünü satın alma eğilimleri ile Pegasus'u tercih edeceğini söyleyen yolcuların arasında anlamlı bir farklılık mevcuttur. Buna göre THY'yi tercih edeceğini belirten yolcuların yan ürünleri satın alma eğilimleri fazladır. THY ve Pegasus havayollarının iş modelleri birbirinden oldukça farklıdır ve THY bir ağ taşıyıcısı olarak hâlihazırda birçok ürünü ücretsiz biçimde bilet fiyatı içerisinde sunmaktadır. Dolayısıyla THY yolcuları genel olarak havayolu hizmetini yan ürünleri ile birlikte satın almaya alışkın olduklarından; bu hizmetlerin bilet ücretinden ayrı fiyatlandıkları durumlarda dahi yolcuların bu ürünleri satın almayı düşünmeleri doğaldır. Diğer yandan Pegasus'un benimsemiş olduğu düşük maliyetli iş modelinin temelini basitleştirilmiş hizmet sunumu, ucuz bilet ve yan ürün satışları oluşturmaktadır. Buna göre Pegasus'u tercih eden yolcuların da yan ürünler için bile olsa fazladan para ödemeye istekli olmamaları olağan karşılanabilir.

Bu çalışmanın sonuçları alanyazındaki diğer çalışmaların sonuçlarından bazı yönlerden farklılık göstermektedir. Diğer çalışmalar havayolu yolcularının yan ürün alma eğiliminde olduklarını göstermektedir. Özellikle Peksatıcı (2016) çalışmasında havayolu yolcularının birçok yan ürün ve hizmet için ödeme yapmayı kabul ettikleri sonucuna varmıştır. Bu farklıı̆ı̆ çalışmaya konu olan havayollarının iş modeli farklılıklarından kaynaklanması olasıdır. Bu çalışmada Türk iç hat pazarında faaliyet gösteren tüm taşıyıcılar seçilmiştir. Bunlar arasında ağ taşıyıcıları ve düşük maliyetli taşıyıııların olması faktörünün katılımcı profilini ve görüşlerini farkılıştırması beklenebilir. Ayrıca, katıımcıların demografik özellikleri ile ödeme istekliliği arasında anlamlı bir ilişkinin bulunmadığı sonucunun elde edilmesi de araştırmanın diğer bir farklılığıdır.

Bu çalışmada iç hat havayolu yolcularının yan ürün satın alma istekliliklerinin düşük olduğu sonucuna varılmıştır. Önceden bilet fiyatı dâhilinde olan havayolu yan ürünlerinin bilet fiyatı haricinde ayrı ayrı fiyatlandırılması Türkiye iç hat yolcuları için pek de kabul edilebilir bir durum değildir. Araştırmanın en dikkat çekici yanı ise, katılımcılara yan ürünler için ödeyebilecekleri en fazla ücret sorulduğunda katılımcıların çoğunluğunun kendileri için önemli olarak gördükleri dört ürün için ücret belirtmeleridir. Bunlar, alkolsüz içecek, sandviç, ücretli bagaj ve sıcak yemektir. Buradan iki değerlendirme yapılabilir. Birincisi, katılımcılar bu ürünleri satın alma durumu ile karşı karşıya kalmalarını daha olası görmüş olabilirler. İkincisi ise, uygun fiyatlar dahilinde katılımcıların bu ürünleri satın alma düşüncesinde olduklarıdır. Buna karşın uçak içi eğlence ve uçağa binişte öncelik hizmetlerinin katılımcıların birçoğu tarafından satın alınması pek düşünülmemiş olabileceğinden, bu ürünler için ödemeye razı oldukları en yüksek fiyatı belirtmekten kaçınmışlardır. Buna göre, iç hat yolcuları kendileri için "makul" gelen bir fiyattan sunulması durumunda bazı yan ürünleri satın alma niyetinde olabileceklerini belirtmektedirler. Buna karşın, gerçekte satın alma davranışını ölçen sorularda ise satın alma oranı düşük 
çıkmıştır. Dolayısıyla Türk yolcuların fiyatları yüksek bulması ya da yüksek fiyat algısı nedeniyle satın alma konusunda çekinik davranması da mümkündür. Diğer yandan bu çalışma yalnızca iç hatları kapsadığından yolculuk süresinin nispeten kısa olması ve gidilen havaalanının yabancı bir ülkede olmaması benzeri faktörler de göz ardı edilmemelidir. Kısa yolculuklarda kişisel gereksinimler fazla olmazken, yurtdışına çıkışlarda farklı yemek kültürleri nedeniyle yolcunun uçakta daha fazla yiyecek-içecek tüketmesi beklenebilir. Gelecekte araştırmanın dış hatlarda ve nispeten uzun yolculukları da kapsayacak biçimde genişletilmesi ile önemli bulgular elde edilebilir. Araştırma bulgularının, havayolu tüketicilerinin davranışları ile ilgili diğer çalışmalara ve Türk iç hat havayolu pazarında faaliyet gösteren havayolu işletmelerine yol göstermek adına faydalı olacağı düşünülmektedir.

\section{KAYNAKLAR}

Belcombe, K., Fraser,I. ve Harris,L.(2009). "Consumer willingness to pay for in-flight service and comfort levels: A choice experiment", Journal of Air Transport Management, 15,221-226.

Belobaba, P. (2015). "The Global Airline Industry". Chicester: John Wiley \& Sons.

Bockelie, A., \&Belobaba, P. (2017).“Incorporating ancillary services in airline passenger choice models".Journal of Revenue and Pricing Management, 1-16.

Büyüköztürk, Ş. (2005), “AnketGeliştirme”.Türk Eğitim BilimleriDergisi, Cilt.3, No.2, ss.133-151.

Garrow, L. ve Mumbower, S.(2012). “Assessment of product debundling trends in the US airline industry: Customer service and public policy implications". Transportation Research Part A, 46,255-268.

Ideaworks.(2016). 2016 Ancillary Revenue Yearbook.

O'Connell, J., \& Warnock-Smith, D. (2013).“An investigation into traveler preferences and acceptance levels of airline ancillary revenues".Journal of Air Transport Management 33, 21-21.

O'Connell, J., \& Williams, G. (2011). “Air Transport in the 21st Century: Key Strategic Developments”. Ashgate.

Peksatıcı, Ö. (2016). "Ancillary revenue opportunities in Turkish domestic aviation market". International Journal of Economics, Commerce and Management, 4(1), 175-206.

SITA.(2014). 2014 Airline IT Trends Survey.

Sorensen, J., \& Lucas, E. (2011).Loyalty by the Billions. www.ideaworkscompany.com: http://www.ideaworkscompany.com/wpcontent/uploads/2012/05/2011LoyaltybytheBillions-report.pdfadresindenalınmıştır.

Şengür, Y. ve KuyucakŞengür, F. (2017). “Airlines define their business models”. World Review of Intermodal Transportation Research, 6, 2, 141-153.

Vasigh, B., Taleghani, R., and Jenkins, D. (2012), "Aircraft Finance: Strategies for Managing Capital Costs in a Turbulent Industry", J. Ross Publishing, Ft. Lauderdale, FL.

Wit, J. ve Zuidberg, J. (2012). “The growth limits of the low cost carrier model”, Journal of Air Transport Management, 21, 17-23.

Wittmer, A. ve Rowley, E. (2014). “Customer value of purchasable supplementary services: The case of a European full network carrier's economy class", Journal of Air Transport Management, 34, 17-23. 